\title{
ASSESSMENT OF NURSES' KNOWLEDGE AND PRACTICE REGARDING FLUIDS AND ELECTROLYTE IMBALANCE IN CRITICAL CARE UNITS
}

\author{
Heba Mohamed Ahmed Hassan 1; Prof. El-sayed Elmeghawry El-sayed 2; Prof. Sahar \\ Yassien Mohammad ${ }^{3}$; \& Dr. Dina El Tabey Sobh Sobeh ${ }^{4}$
}

M.Sc., Faculty of Nursing, Port Said University ${ }^{1}$, Professor of Internal Medicine, Faculty of Medicine, Al-Azhar University ${ }^{2}$, Professor of Medical Surgical Nursing, Ain Shams University $^{3}$, Lecturer of Medical Surgical Nursing, Faculty of Nursing, Port Said University ${ }^{4}$

\begin{abstract}
Background: The accurate monitoring of fluid balance activities is a vital part of patients $^{\text {ee }}$ baseline information, which guides medical and nursing interventions to achieve physiological stability. Inaccurate monitoring of fluid balance especially in critically ill patients can deteriorate patients ${ }^{\text {ee }}$ conditions. Aim of this study was to assess nurses' knowledge and practice regarding fluid and electrolyte imbalance in critical care units. Subjects and method: Design: A descriptive research design was used. Subjects: A convenient sample was used (72 nurses) all nursing staff working in above mentioned setting. Setting: Intensive care units in Damietta General Hospital. Tools: Two tools were used to collect the needed data; nurses 'knowledge Questionnaire and nurses' observation checklist. Results show a defect in the nurses' knowledge and practice as for general knowledge of nurses had unsatisfactory knowledge with Mean \pm SD 26.8 \pm 5.6 . for general nurses' practice regarding fluid \& electrolyte imbalances monitor and management $97.2 \%$ of nurses had unsatisfactory level. of practice with Mean \pm SD 57.3 \pm 7.5 . Conclusion: The study concluded that there is a defect in the nurses' knowledge and practice. Recommendations: Continued nursing education and updating knowledge in the intensive care units should be organized regularly.
\end{abstract}

Keywords: fluid and electrolyte imbalance, nurse's knowledge, practice. 


\section{INTRODUCTION}

Fluid balance is a term used to describe the balance of the input and output of fluids in the body to allow metabolic processes to function correctly, around 52\% of total body weight in women and $60 \%$ in men is fluid (Welch, 2011). The body is equipped with homeostatic mechanisms to keep the composition and volume of body fluids within narrow limits (Stewart, 2012).

Fluid and electrolyte disorders are among the most common clinical problems encountered in the setting of intensive care. Critical disorders such as severe burns, trauma, sepsis, brain damage, and heart failure lead to disturbances in fluid and electrolytes homeostasis. Possible mechanisms include reduced perfusion to the kidney due to hypovolemia or hypotension; activation of hormonal systems such as renin-angiotensinaldosterone system and vasopressin; and tubular damage caused by ischemic or nephrotoxic kidney damage, including renal insult caused by a myriad of medications used in the intensive care. In addition, inappropriate administration of fluid and electrolyte should be considered in the diagnosis and treatment of fluid and electrolyte disturbance (Lee, 2010).

Fluid and electrolyte imbalance is an important everyday performance in the intensive care unit, it's an integrate part of everyday care of the patients (Culleiton, \& Simko, (2011). Patients are admitted to intensive care units because a physiological crisis threatens one or more bodily systems, and their life. Critically ill patients are at great risk for fluid and certain electrolyte imbalances. Proper fluid therapy and treatment of electrolyte abnormalities make a major difference in the survival rate of critically ill (Eckman \&lobus, 2010).

The most effective therapy is careful management of fluid balance, which involves thoughtful assessment of hydration, a fluid treatment plan personalized for the specific patient, repeated and frequent reassessment of fluid and electrolyte balance, and appropriate changes in the treatment plan in response to the rapidly changing clinical situation of the critically ill patients (Harbir \& Madh, 2009). To promote adequate hydration, safe and effective nursing care, nurses should always report any significant abnormalities identified in patients' fluid record (Desborough, 2010).

The nurse is a vital member in the health care team who assess and identifies changes in fluid and electrolytes balance. Understanding the basic principles of fluid and electrolyte 
imbalance in the body is essential in assessing the patient, planning interventions, and evaluates the effects of care. Knowledge of which electrolytes can be affected by various disorders and an ability to quickly identify the signs and symptoms of electrolyte imbalance can ensure prompt treatment, thereby circumventing more serious complications (Ignatavicius \& Workman, 2010).

\section{AIM OF STUDY}

The aim of the study was to assess nurses' knowledge and practice regarding fluid and electrolyte imbalance.

\section{SUBJECTS AND METHOD}

\section{(I) TECHNICAL DESIGN}

\section{Research design:}

A descriptive research design was used in the current study.

\section{Setting:}

The study was conducted at the intensive care units in Damietta general hospital.

\section{Sample:}

A convenient sample of all staff nurses working in intensive care units in Damietta general hospital, the total number were (72).

\section{Tools For Data Collection:}

Tool (I): Nurses 'Knowledge questionnaire

\section{Part 1: Demographic Data:}

Demographic data includes data related to (age, level of education, critical care experience, etc....).

Part 2: Nurses 'Knowledge questions:

Nurses' knowledge questionnaire to assess nurses' knowledge in relation to fluid and electrolyte balance and imbalance including function of electrolyte, forms of fluids and electrolyte imbalance and the clinical features of each one, the underlying causes of imbalance and its management, complications and nurse's responsibilities). It composed of (58) MCQ questions and (1) table matching.

Scoring system: 
Nurses' knowledge assessment consisted of (59 MCQ questions) and the answer was evaluated using model key answer prepared by the researcher, the score (2) for complete correct answer, the score (1) for incomplete correct answer and the score (0) for incorrect answer. Total knowledge score was (118). Total knowledge was considered as:

- Satisfactory if score $\geq 75 \%$ of the maximum score.

- Unsatisfactory if score $<75 \%$ of maximum score.

Tool II: Nurses' observational checklist:

Developed by the researcher after reviewing the most recent and relevant literature (McCance \& Huether 2010) to assess nurses' practice regarding fluid and electrolyte imbalance through the following:

1- Fluid \&electrolytes monitoring: assess nurses' practice in relation to fluid and electrolyte balance and imbalance including the clinical features of each one consisted of (12 items).

1- Fluid \&electrolytes imbalance management: Including nurse's responsibilities for managing of fluid and electrolyte imbalance consisted of (39 items).

Scoring system:

Practice observational checklist consisted of (51 questions) and the answer was evaluated using model key answer prepared by the researcher, and the score (2) for completely done, the score (1) for partially done and the score (0) for not done. Total practice score was (102).

Total practice was considered as:

- Satisfactory if score $\geq 75 \%$ of the maximum score.

- Unsatisfactory if score $<75 \%$ of maximum score

\section{(II) Operational Design:}

Preparatory phase

It included reviewing of related literature and theoretical knowledge of various aspects of the study using books, articles, internet periodicals and Journals to develop the tools for data collection.

\section{A. Content tool Validity:}


Content validity was conducted to test the tool for appropriateness, relevance, correction and clearance through a jury of 15 experts from nursing faculty staff and medicine faculty staff of Ain Shams university, Cairo University, Helwan university , Port said university and Baniswif university, their opinions were elicited regarding the tool format layout, consistency and scoring system.

\section{Reliability:}

Testing reliability of proposed tool was done by cronbach's alpha test. Cronbach alpha value was 0.74 for nurses' knowledge questionnaire sheet and a cronbach alpha value was 0.90 for nurses' practice observational checklist indicating reliability of the developed data collection tools.

\section{B. Pilot study:}

Prior to performing the actual study, a pilot study was carried out on $10 \%$ of nurses to test the applicability, visibility, clarity of questionnaire and arrangement of items, and estimate the time needed for each sheet. The nurses included in the pilot study were excluded from study. Some modifications were done to knowledge and practice tools based on the pilot study and opinion of experts.

\section{Field of work:}

The researcher assesses nurses' knowledge and practice by collecting data regarding fluid and electrolyte imbalance by using (tool I and tool II). The researcher attending to study setting two days weekly to collecting data from study subjects through observation checklist and questionnaire, every nurses take time ranged from 20 minutes to 35 minute to complete required data

\section{(III) Administrative Design}

An official letter has issued from the Faculty of Nursing, Port-said University to the directors of intensive care units of selected hospitals to obtain their permission to conduct the study.

\section{Ethical Consideration:}

After obtaining the official permission to conduct the study, the studied nurses were informed with the aim and nature of the study. It was emphasized that the participation is voluntary and confidential and anonymity of the subject was assured through coding of data. 


\section{(Iv) Statistical Design:}

The data obtained has organized, categorized, tabulated and analyzed by using SPSS (Statistical Package for Social Sciences), soft- ware program with suitable version, which will be applied to answer the research objectives and hypotheses.

\section{RESULTS:}

Table (1): Illustrate that $56.9 \%$ of studied nurses were in age group between $20-<30$, with mean age of $27.7 \pm 6.5$, and $43.1 \%$ of them had secondary school diploma. In addition to $70.8 \%$ received training in critical care. $65.3 \%$ of studied nurses displayed no need for training.

Table (2): illustrates that, for general knowledge regarding hypovolemia, $27.8 \%$ of nurses had satisfactory knowledge. Concerning hypervolemia, $4 \%$ of nurses had satisfactory knowledge with Mean \pm SD 35.2 \pm 18.6 .

Table (3): represents that, for general knowledge regarding about $\mathrm{Na}, \mathrm{Cl}, \mathrm{Mg}, \mathrm{Po} 4$ and K $100.0 \%$ of nurses had unsatisfactory knowledge with Mean+SD 26.8 \pm 5.6 .

Table (4): clarifies that, for nurses' practice regarding nurses' practice regarding fluid \& electrolyte imbalances monitor and management $97.2 \%$ of nurses had unsatisfactory level of practice with Mean \pm SD 57.3 \pm 7.5 . 
Table (1): Percentage distribution of demographic characteristics of the studied nurses

\begin{tabular}{|c|c|c|}
\hline \multirow{2}{*}{ Demographic characteristics } & \multicolumn{2}{|c|}{ Studied nurses $(\mathrm{n}=72)$} \\
\hline & No. & $\%$ \\
\hline \multicolumn{3}{|l|}{ Age (years) } \\
\hline Less than 20 & 7 & 9.7 \\
\hline $20-<30$ & 41 & 56.9 \\
\hline $30-<40$ & 21 & 29.2 \\
\hline $40-<50$ & 3 & 4.2 \\
\hline Min-Max & \multicolumn{2}{|c|}{$18.0-45.0$} \\
\hline Mean \pm SD & \multicolumn{2}{|c|}{$27.7 \pm 6.5$} \\
\hline \multicolumn{3}{|l|}{ Educational level } \\
\hline Secondary school diploma & 31 & 43.1 \\
\hline Technical institute diploma & 16 & 22.2 \\
\hline $\mathrm{BSCH}$ in nursing science & 22 & 30.6 \\
\hline Master degree in nursing science & 3 & 4.2 \\
\hline \multicolumn{3}{|l|}{ Received training in critical care } \\
\hline No & 21 & 29.2 \\
\hline \#Yes & 51 & 70.8 \\
\hline \multicolumn{3}{|l|}{ Needed training } \\
\hline No & 47 & 65.3 \\
\hline \#Yes & 25 & 34.7 \\
\hline \multicolumn{3}{|l|}{ Duration of nursing experience (years) } \\
\hline $1<5$ & 41 & 56.9 \\
\hline $5-<10$ & 16 & 22.2 \\
\hline 10 - or more & 15 & 20.8 \\
\hline Min-Max & \multicolumn{2}{|c|}{$1.0-16.0$} \\
\hline Mean \pm SD & \multicolumn{2}{|c|}{$5.1 \pm 4.3$} \\
\hline
\end{tabular}


Table (2): Satisfactory scores of general nurses' knowledge, hypo and hypervolemia $(n=72)$.

\begin{tabular}{|c|c|c|}
\hline \multirow{2}{*}{ Knowledge Scores (\%) } & \multicolumn{2}{|c|}{ Studied nurses $(n=72)$} \\
\hline & No. & $\%$ \\
\hline \multicolumn{3}{|l|}{ General knowledge } \\
\hline Unsatisfactory $(<75 \%)$ & 67 & 93.1 \\
\hline Satisfactory $\quad(\geq 75 \%)$ & 5 & 6.9 \\
\hline Min-Max & \multicolumn{2}{|c|}{$0.0-83.3$} \\
\hline Mean+SD & \multicolumn{2}{|c|}{$47.2 \pm 19.8$} \\
\hline \multicolumn{3}{|l|}{ Hypovolemia } \\
\hline Unsatisfactory $(<75 \%)$ & 52 & 72.2 \\
\hline Satisfactory $\quad(\geq 75 \%)$ & 20 & 27.8 \\
\hline Min-Max & \multicolumn{2}{|c|}{$0.0-91.7$} \\
\hline Mean+SD & \multicolumn{2}{|c|}{$53.7 \pm 19.9$} \\
\hline \multicolumn{3}{|l|}{ Hypervolemia } \\
\hline Unsatisfactory $(<75 \%)$ & 69 & 95.8 \\
\hline Satisfactory $\quad(\geq 75 \%)$ & 3 & 4.2 \\
\hline Min-Max & \multicolumn{2}{|c|}{$0.0-83.3$} \\
\hline Mean \pm SD & \multicolumn{2}{|c|}{$35.2 \pm 18.6$} \\
\hline
\end{tabular}

Table (3): Distribution of satisfactory of nurses' knowledge level of different electrolyte imbalances management among the studied nurses $[\mathrm{n}=72]$

\begin{tabular}{|c|c|c|}
\hline \multirow{3}{*}{ Knowledge Scores (\%) } & \multicolumn{2}{|c|}{ Studied nurses $(\mathrm{n}=72)$} \\
\hline & \multicolumn{2}{|c|}{ Before } \\
\hline & No. & $\%$ \\
\hline Knowledge about $\mathrm{Na}$ and $\mathrm{Cl}$ & & \\
\hline Unsatisfactory $(<75 \%)$ & 72 & 100.0 \\
\hline Satisfactory $(75 \% \leq)$ & 0 & 0.0 \\
\hline Min-Max & \multicolumn{2}{|c|}{$0.0-72.2$} \\
\hline Mean \pm SD & \multicolumn{2}{|c|}{$23.1 \pm 14.7$} \\
\hline \multicolumn{3}{|l|}{ Knowledge about potassium } \\
\hline Unsatisfactory $(<75 \%)$ & 72 & 100.0 \\
\hline Satisfactory $(75 \% \leq)$ & 0 & 0.0 \\
\hline Min-Max & \multicolumn{2}{|c|}{$0.0-46.2$} \\
\hline Mean \pm SD & \multicolumn{2}{|c|}{$12.7 \pm 10.9$} \\
\hline \multicolumn{3}{|l|}{ Knowledge about Calcium } \\
\hline Unsatisfactory $(<75 \%)$ & 72 & 100.0 \\
\hline Satisfactory $(75 \% \leq)$ & 0 & 0.0 \\
\hline Min-Max & \multicolumn{2}{|c|}{$0.0-50.0$} \\
\hline Mean \pm SD & \multicolumn{2}{|c|}{$19.2 \pm 11.8$} \\
\hline \multicolumn{3}{|l|}{ Knowledge about Magnesium } \\
\hline Unsatisfactory $(<75 \%)$ & 72 & 100.0 \\
\hline Satisfactory $(75 \% \leq)$ & 0 & 0.0 \\
\hline Min-Max & \multicolumn{2}{|c|}{$0.0-50.0$} \\
\hline Mean \pm SD & \multicolumn{2}{|c|}{$23.5 \pm 13.9$} \\
\hline
\end{tabular}


Table (4): Scores of nurses' practice regarding fluid \& electrolyte imbalances monitor and management $(\mathrm{n}=72)$

\begin{tabular}{|c|c|c|}
\hline \multirow{3}{*}{ Practice Score (\%) } & \multicolumn{2}{|c|}{ Studied nurses $(\mathrm{n}=72$} \\
\hline & \multicolumn{2}{|c|}{ Before } \\
\hline & No. & $\%$ \\
\hline \multicolumn{3}{|l|}{ Fluid and electrolyte monitor score } \\
\hline Unsatisfied $(<75 \%)$ & 70 & 97.2 \\
\hline Satisfied $(\geq 75 \%)$ & 2 & 2.8 \\
\hline Min-Max & \multicolumn{2}{|c|}{$29.2-79.2$} \\
\hline Mean \pm SD & \multicolumn{2}{|c|}{$56.3 \pm 11.3$} \\
\hline \multicolumn{3}{|l|}{ Fluid and electrolyte management score } \\
\hline Unsatisfied $(<75 \%)$ & 70 & 97.2 \\
\hline Satisfied $(\geq 75 \%)$ & 2 & 2.8 \\
\hline Min-Max & \multicolumn{2}{|c|}{$39.3-79.8$} \\
\hline Mean \pm SD & \multicolumn{2}{|c|}{$57.6 \pm 7.5$} \\
\hline \multicolumn{3}{|l|}{ Total practice score } \\
\hline Unsatisfied $(<75 \%)$ & 70 & 97.2 \\
\hline Satisfied $(\geq 75 \%)$ & 2 & 2.8 \\
\hline Min-Max & \multicolumn{2}{|c|}{$39.8-77.8$} \\
\hline Mean \pm SD & \multicolumn{2}{|c|}{$57.3 \pm 7.5$} \\
\hline
\end{tabular}

\section{DISCUSSION:}

Fluid balance monitoring is a part of the scope of nurses ${ }^{e e}$ practice. Therefore, nurses working in ICUs are responsible and accountable for the accurate recording and calculation

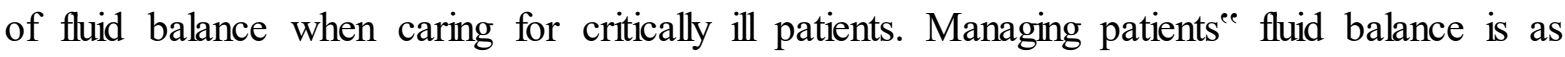
equally important as carrying out any other patient care activity for the critically ill. The accurate monitoring of fluid balance activities is a vital part of patients ${ }^{\text {ee }}$ baseline information, which guides medical and nursing interventions to achieve physiological stability. Inaccurate monitoring of fluid balance especially in critically ill patients can deteriorate patients ${ }^{\text {ee }}$ conditions. Therefore, fluid balance should be monitored and recorded accurately for patients in intensive care units (ICUs) (Herbert \& Elsayed, 2016).

Regarding demographic characteristics of the studied group in the current study showed 
that more than half of the studied nurses were at age $20-<30$, less than half of them were diploma nursing, more than two third of them were received training courses, more than half of them said that they didn't need any training courses.

Regarding to the duration of nursing experience, half of them have experience from $1<5$ years ago, which mean that the most of them are fresh graduated. According to the current study results, in addition that most of them are not highly qualified nurses so the diploma nurses should seek to obtain a more advanced qualification and training. In this respect, the American Association of colleges of nursing (AACN) encourages lifelong learning and offer incentives for nurses seeking to advance their education (AACN, 2014).

The current study showed that, the majority of nurses had un satisfactory knowledge regarding fluids and electrolyte, this sustained results might be referred to that, the majority of the studied nurses were nursing diploma which makes them less qualified to be at the same level with the bachelor nursing degree.

Respectively was similar to (Mogileeswari \& Ruth, 2016) who conducted a study to assess nurses ${ }^{e e}$ knowledge and practice regarding fluid therapy. However, (Diacon \&Bell, 2014) reported that critical care nurses are equipped with theoretical and practical knowledge about fluid balance monitoring.

As regarding nurses' level of practice the current study clarified that, almost all nurses were performed unsatisfactorily regarding monitoring and managing of fluid and electrolyte abnormalities. The result of the pre-test, might be related to a main cause of inaccurate fluid balance monitoring was a shortage of nursing staff and workload in ICU. Also might be because fluid balance monitoring is considered a routine nursing measure; nurses might think that they are competent in fluid balance calculation and monitoring and do not look forward updating their knowledge.

The results of the current study are in the same line with (Vincent \&Mahendiran, 2015) used e-Learning and verbal presentation in their study to raise nursese ${ }^{e e}$ awareness around fluid balance, after intervention, the researchers found that to improve nursing practice, adequate knowledge is needed. 
Also the Nursing and Midwifery Council (NMC) has issued clear guidance on the importance of record keeping and states that:' Nurses are required to have the knowledge and competence to care for patients, which includes understanding the indications for and importance of fluid balance charts. Fluid management should be accorded the same status as a drug prescription (Sarah, 2015).

\section{CONCLUSION}

Based on the results of the present study, the studied nurses had unsatisfactory level of knowledge and practice regarding fluids and electrolyte imbalance.

\section{RECOMMENDATIONS}

Recommendations For Nurses:

- Continues education for nurses are required to have the knowledge and competence to care for patients, which includes understanding the indications for and importance of fluid balance charts and Fluid \&electrolyte imbalance management.

- Novice nurses should be trained adequately regarding assessment and monitoring of fluid balance.

\section{REFERENCES:}

American Association of Colleges of Nursing (2014). Enrollment and graduations in baccalaureate and graduate programs in nursing. Washington, DC: Author.

Desborough, J. (2010). The stress response to trauma and surgery. Br J Anaesth, 85, 109-17.

Diacon A, \& Bell J. (2014). Investigating the recording and accuracy of fluid balance monitoring in critically ill patients. S Afr J Crit Care, 30 (2), 55- 7.

Eckman, M. \& Lobus, O. (2010). Fluid and electrolyte an incredibility easy pocket guide (2nd ed.). New York: Lippincott Williams \& Wilkins).

Harbir, S., kholi, A. \& Madhu, C. (2009). Oxford journal of Nephrology dialysis and transplantation, 212-217. 
Herbert, L., \& Elsayed, M. (2016). Fluid and Electrolyte Balance in the Intensive Care Unit - Trickle or Fluids http:// www. appraisal. nes.scot.nhs.uk/media/179709/fluidposter.pdf retrieved May 14, 2016.

Ignatavicius, D. \& Workman, M. (2010). Medical-Surgical Nursing: PatientCentered Collaborative care. 6th ed. St. Louis, MO: Elsevier. Pp. 170-198.

Imel, E. A., \& Econs, M. J. (2012). Approach to the hypophosphatemic patient. The Journal of Clinical Endocrinology \& Metabolism, 97(3), 696-706.

Culleiton, A. L., \& Simko, L. C. (2011). Keeping electrolytes \& fluids in balance, part 2. Nursing2020 Critical Care, 6(3), 27-32.

National patient safety goals (2010). Retrieved from http://www.jointcommission. org/patient safety/national patient safety goals. accessed at 24/6/2016.

Lee, J. (2010). Fluid and electrolyte disturbances in critically ill Patients. Electrolyte blood press, 8 (2), 72-81. Available at: http//www.ncbi.nlm.nih.gov/ pmc/articles/ PMC3043756/?report=classi. Accessed on: 14-2-2015.

McCance, K., Huether, SE. (2010). Pathophysiology: the biologic basis for disease in adults and children (6 th ed.). Mosby.

Mogileeswari, P., Ruth, M. (2016). Knowledge and practice regarding fluid and electrolyte replacement therapy for patient with burns. International Journal of Multidisciplinary Research and Development, 3(4), 217-20.

Sarah, M. (2015). The ins and outs of fluid balance in the acutely ill patient. British Journal of Nursing, 24(1).

Stewart, P. A. (2012). Modern quantitative acid-base chemistry. Canadian journal of physiology and pharmacology, 61(12), 1444-1461. 
Vincent, M., \& Mahendiran, T. (2015). Improvement of fluid balance monitoring through education and rationalization. BMJ Quality Improvement Reports. u209885.w4087 doi: 10.1136/bmjquality. u209885.w4087. http://qir.bmj.com/ retrieved on May 14, 2016.

Welch, K. (2011). Measuring and managing fluid imbalance, Fluid balance learning. Disability Practice, 13 (6), 33-38.

$$
\begin{aligned}
& \text { تقييم معرفة الممرضـات تـجـاه اختـلال الـسوائـل و الشــوارد في وحدات الـعــايـة المـركــزة } \\
& \text { هبة محمد أحمد حسن } 1 \text { ؛ السيد المغاوري السيد 2. سحر ياسين محمد 3؛ د. دينا التابعي صبح صبيح4 }
\end{aligned}
$$

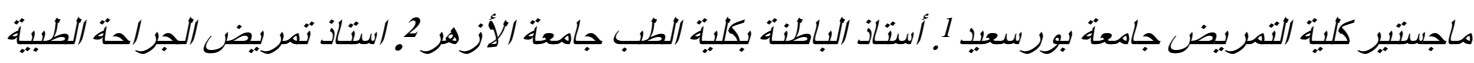

$$
\begin{aligned}
& \text { جامعة عبن شهس } 3 \text {, مدرس تمريض الجر/حة الطبية. كلبة التمريض جامعة بورسعبي } 4
\end{aligned}
$$

\section{الـخـلاصــة}

تعتبر المتابعة والرصد الدقيق لتوازن السوائل والشوارد في جسم الانسان هي جزء حيوي ومهم من المعلومات الأساسية الخاصه بالمريض ، والتي توجه التخخلات الطبية والتمريضية لتحقيق الاستقرار الفسيولوجي. و واذا كانت هذه المتابعة غير دقيقة وخاصة في المرضى الذين يعانون من أمر اض خطيرة فإنه من المكن أن يؤدي ولي ولهي

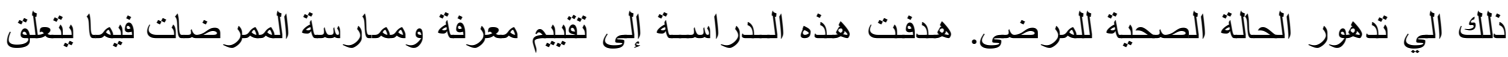
باختـلال الـسوائل و الشـوارد في وحدات العنـايـة المـركـزة..وقد أخذت العينة من جميع التمريض العامل بوحدات الرعايه الحرجه بمستشفي دمياط العام و هم حوالى (72) ممرضده، واستخدم أداتين لجمع البيانات اللازمة؛ ورقة استبيان منظم لتقييم المعرفة لدي الممرضات، و ورقه ملاحظه لتقييم ممارسات التمريض. وقد كثفت

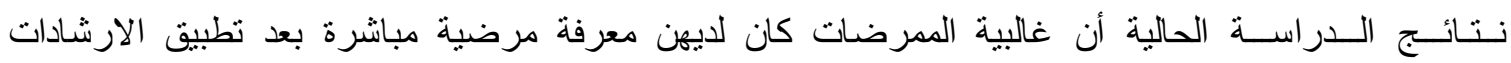

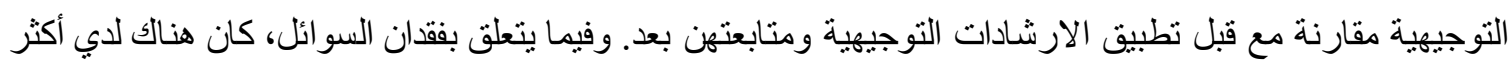
من تلثي الممرضات معرفة مرضية مباشرة بعد نطبيق الإرشادات واتباعها مقارنة مع قبل نطبيق الإرشادات

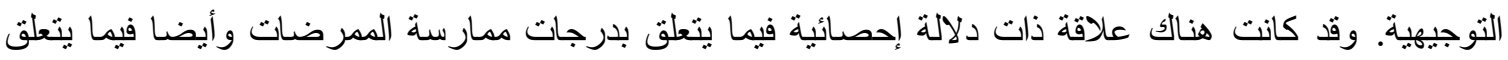
بالخلل في السو ائل والثوارد قبل ومباشرة بعد تطبيق الارشادات التوجيهيه ومتابعة بعد تطبيقات الإرشادات التوجيهية

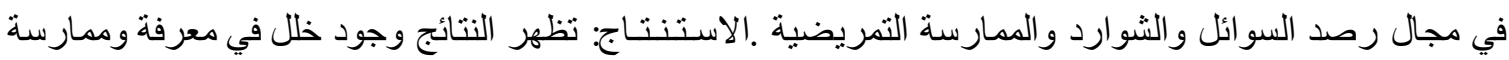

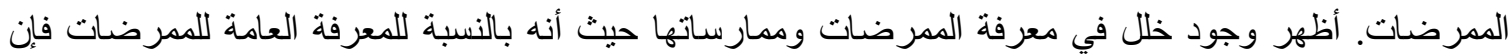

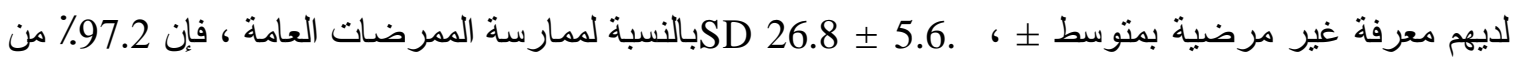

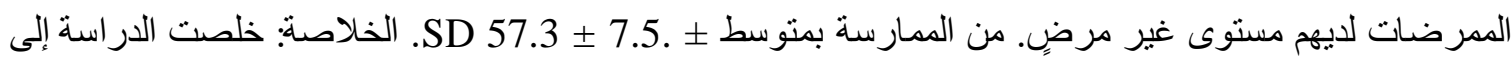
وجود خلل في معرفة وممارسة الممرضات. وأوصت نـتائج الـدراســة الحالية بأن يستمر تعليم التمريض في الحصول على المعرفة وتحسين كفاءة الرعاية التمريضية المقدة للمرضى، والتي تشمل فهم مؤشرات وأهمية مخططات توازن السو ائل و الشوارد وعدم توازنها. الكلمات المرشدة: اختلال السوائل و الشوراد، معرفة الممرضين ، الممارسات 